\title{
Abundance and composition of the medium to large-sized mammals in a private area of a REDD+ project in Acre, Brazil
}

\author{
André Luis Moura Botelho ${ }^{1 * \mathbb{D}, \text { Luiz Henrique Medeiros Borges }{ }^{2} \text { \& Brian McFarland }}$ \\ ${ }^{1}$ Instituto Federal de Educação, Ciência e Tecnologia do Acre, Campus Rio Branco, Rio Branco, AC, Brasil \\ ${ }^{2}$ Universidade Federal do Pará, Programa de Pós Graduação em Ecologia, Instituto de Ciências Biológicas, \\ Belém, PA, Brasil \\ ${ }^{3}$ Carbonfund.org Foundation, New York, United States \\ *Corresponding author: André Luis Moura Botelho, e-mail: botelho.alm@gmail.com
}

BOTELHO, A. L. M., BORGES, L. H. M., McFARLAND, B. Abundance and composition of the medium to large-sized mammals in a private area of a REDD+ project in Acre, Brazil. Biota Neotropica. 18(3): e20170487. http://dx.doi.org/10.1590/1676-0611-BN-2017-0487

\begin{abstract}
The implementation of private areas focused on conservation of species and habitats, combined with REDD+ policies, has become an important ally for biodiversity conservation, expanding the conservation areas of the most varied habitats, covering key groups such as large mammals, which are extremely important for the maintenance of ecosystem services. In the upper region of the Purus River in Acre, Brazil, an inventory was carried out using camera-traps, of medium and large mammals community in a private REDD + area, known as the Purus Project. A total of 19 species of mammals were recorded with an effort of 1859 trap-nigths, including rare, endangered and key species. It is estimated that the richness for the area is of 22 species. Endangered and rare species such as the tapir (Tapirus terrestris) and the short-eared dog (Atelocynus microtis) presented high rates of relative abundance compared to other Conservation Units (UCs). The richness of medium to large-sized mammals recorded in the Purus Project underscores the importance of REDD+ in private areas for the conservation of this group, given the challenges for inclusion and creation of new protected areas. REDD+ projects in privates' areas become an important component for conservation of species and the connection between public conservation units favoring the spread of species and populations between areas, and consequently the gene flow.
\end{abstract}

Keywords: Private Areas, Conservation, Camera-trap, Maintenance of Biodiversity.

\section{Abundância e composição de mamíferos de médio e grande porte em uma área privada de projeto REDD+ no Acre, Brasil}

\footnotetext{
Resumo: A implementação de áreas privadas voltadas para conservação de espécies e habitats, aliadas a políticas de REDD+, tem se tornado importante aliada para conservação da biodiversidade, ampliando as regiões de conservação dos mais variados habitats, abrangendo grupos chaves como grandes mamíferos, extremamente importantes para manutenção dos serviços ecossistêmicos. Na região do alto rio Purus, Acre, Brasil, foi realizado um inventário utilizando armadilhas fotográficas, da comunidade de mamíferos de médio e grande porte de uma área privada de REDD+, o Projeto Purus. Foram registradas 19 espécies de mamíferos, com um esforço de 1.859 armadilhas-noite, incluindo chaves, raras e ameaçadas de extinção. Estima-se que a riqueza esperada para a área seja de 22 espécies. Espécies ameaçadas e raras como a Anta (Tapirus terrestris) e o Cachorro-do-mato (Atelocynus microtis) apresentaram taxas de abundância relativa elevadas, comparadas com outras UCs. A riqueza de médios e grandes mamíferos registrados na região do Projeto Purus ressalta a importância de REDD+ em áreas privadas para conservação deste grupo, dado os desafios para inclusão e criação de novas áreas protegidas públicas. Assim projetos de REDD+ em áreas privadas se tornam um importante componente para conservação de espécies e para a conexão entre Unidades de Conservação públicas favorecendo a dispersão de espécies e populações entre áreas, e consequentemente o fluxo gênico.
}

Palavras-chave: Áreas privadas, Conservação, Armadilhas Fotográficas, Manutenção da Biodiversidade. 


\section{Introduction}

Although the surface of the Earth is covered by approximately 16,200 areas of legal protection with about 28 million $\mathrm{km}^{2}$ (Watson et al. 2014), most of these areas cover very restricted geographic regions and habitats (Gallo et al. 2009). In Brazil, for example, about $1,500,436 \mathrm{~km}^{2}$ of area are included in protected areas (MMA 2017). Most of these areas cover regions with little productive soils and low implantation costs (Norton 2000, Scott et al. 2001, Rouget et al. 2003). According to Norton (2000), the network of existing legal protected areas in the world is not adequate for biodiversity conservation, due to the costs to create and maintain these areas, as well as factors such as decrease and changes in the regulation of these areas (Gallo et al. 2009, Marques \& Peres 2015). In a review, Rodrigues et al. (2004) showed that $11.4 \%$ of approximately 11,600 vertebrates are covered in public Conservation Units (UCs), and demonstrate that the percentage of area already protected in a given country or biome is a very poor indicator of additional conservation needs.

A possible solution to conservation biodiversity, would be to include private areas conservation (Gallo et al. 2009). According to Pence et al. (2003), associating private and public areas for conservation could save up to $80 \%$ of the costs directed to UCs. Although Private Conservation Areas are ignored from conservation statistics, academia and even national conservation plans, studies show the ability to conserve millions of hectares of land (Norton et al. 2000, Scott et al. 2001, Rouget et al. 2003, Gallo et al. 2009). For example, private areas preserve twice more types of vegetation than public conservation units in Australia and South Africa (Gallo et al. 2009), improving the connection between UCs, favoring maintenance of local fauna and flora. This association is important because it increases the conservation area in the region, protecting distinct and endangered habitats (Gallo et al. 2009, Polack et al. 2016).

In this scenario, areas that have REDD+ projects meet the need to combine conservation between private and non-private areas. REDD+ Policies (Reducing Emissions from Deforestation and Forest Degradation) has sought to enhance actions of initiatives that focus on the conservation of biodiversity (Harvey et al. 2010). REDD+ is of particular importance in this scenario, since it considers the need to monitor biodiversity and not only the carbon stock of the areas (Harvey et al. 2010). This broad vision is needed for the sustainability of REDD+, since the fauna and flora are closely related, and the conservation of mammalian dispersers and seed predators is of extreme importance for the conservation of trees of high commercial value (Terborgh et al. 2008, Estes et al. 2011, Culot et al. 2017). However, most REDD+ projects have failed in goals and plans, including conservation and monitoring of biodiversity (Panfil \& Harvey 2016). In a review, Panfil \& Harvey (2016) found that in $80 \mathrm{REDD}+$ projects listed around the world, none provided detailed information on the sampling design, methodology for measuring indicators, or how data would be analyzed, although some indicated monitoring of biodiversity. In addition, none reported data on impacts of population sizes of threatened species nor provided other direct measures of status of fauna communities. This makes it difficult to assess how REDD+ projects have fulfilled their roles in biodiversity conservation.

Among the most varied vertebrate taxa, mammals of medium and large sizes stand out because they play fundamental roles in the regulation and structuring of forest ecosystems, acting in different ecological services, such as seed dispersal and predation, fruit and seedling removal, agent pollinators and top-chain predators. Much of the world's mammal diversity is found in the neotropical region (Brown 2014). 701 species of the 5,400 known mammals (Schipper et al. 2008), occur in Brazil, a total of 399 species were identified in the Amazon region, and the most diverse, with approximately $58 \%$ of the endemic species of the region (Paglia et al. 2012).

Despite their great importance for tropical forest ecosystems, large mammals are severely threatened by the advance of the agricultural frontier and recent projects to create hydropower plants (Peres 2001, Soares-Filho et al. 2006, Benchimol \& Peres 2015). In addition, hunting activity in the Amazon has shown to be an important cause in the loss of species during the "Anthropocene age" (Peres 2000a, Dirzo et al. 2014, Peres et al. 2016), capable of altering different ecosystem services, such as seed dispersal, and also causing changes in the structure of the plant community (Peres 2000b, Stoner et al. 2007, Terborgh et al. 2008, Dirzo et al. 2014, Culot et al. 2017). The disappearance of mammals in forest ecosystems can have a direct effect on the structure of the plant community and the food chain (Stoner et al. 2007, Dirzo et al. 2014). The main change is the increase in the abundance of plant species that have no dispersion associated with vertebrates, to the detriment of other species with large seeds that are dispersed by large vertebrates (Terborgh et al. 2008, Culot et al. 2017). Such a change in plant community caused by defaunation is detrimental to the carbon market, since large biomass trees can have their recruitment reduced by the absence of their dispersers, reducing the carbon stock of the areas (Bello et al. 2015, Peres et al. 2016)

Acre is considered of extreme importance for the conservation of mammals. The State has approximately $86 \%$ of its territory covered by forests and is situated in one of the areas with the most endemic plants of the Amazon (Maury 2002, INPE 2016). Approximately $47 \%$ of the State is covered by protected areas, including public UCs and Sustainable Use Units totaling 5,198,273 ha (SEMA 2010). In addition, in Acre, mammal richness is estimated at 203 species, corresponding to $29 \%$ of Brazilian mammals (SEMA 2010) and more than half of its territory is considered as "extreme" and "very high" protection areas for the conservation of biodiversity, identified by the MMA (2002).

The knowledge on wild mammals in the Amazon region is still very scarce and has several gaps. Studies on medium and large mammals in the state of Acre have been carried out mainly in public protected areas, and use a variety of sampling methods to record the existing fauna, from census surveys, linear transects (Calouro 2005), track counting (Borges et al. 2014), camera-traps (Botelho et al. 2012) to other methods (Borges et al. 2015).

Given the lack of information related to the occurrence, distribution and the need to understand the importance of private areas for mammal conservation, here we present the first study of medium to large-sized mammals, with a consistence sampling design and methodology in a REDD+ project area. The main objective was to identify the community of medium to large mammals in an area of REDD+, evaluating mainly the richness of species composition, their abundances, and their activity patterns. We also held brief comparisons with studies conducted in public conservation units. 


\section{Material and Methods}

\section{Study area}

The study was conducted in an area of REDD+ known as the Purus Project, located in a forest area of 34,702 ha in the municipality of Manoel Urbano, state of Acre, Brazil. The project area is divided into two plots (Seringal Itatinga and Seringal Porto Central) located along the Purus River (Figure 1), with only $1.4 \%$ of the forest area being converted into an open area or pasture with more than $98 \%$ forest (Eaton \& Andrade 2012). The Purus Project is bordered by the CazumbáIracema Extractive Reserve, and is located near the Indigenous Area of the upper Purus River and the Chandless State Park, functioning as an extension of protected areas in the upper Purus region. The area is inhabited by traditional communities, with occur in low human density ( 0.29 habitants $/ \mathrm{km}^{2}$ ), which are concentrated on the banks of the river (Eaton \& Andrade 2012). Two main vegetable typologies were identified in the area: Open Forest with Palm of Alluvial Influence, which is smaller and concentrated in areas near the river and Open Forest with Bamboo and Palms covers the largest area of the Purus Project area, located further away from the Purus River (Eaton \& Andrade 2012).

\section{Sampling of mammals}

The community of medium and large mammals was inventoried with the use of 10 BUSHNELL TROPHY CAM HD traps. Sampling stations were installed, consisting of a tree-tied trap approximately
30 to $40 \mathrm{~cm}$ above the ground. The sampling stations were installed at regular distances of $1 \mathrm{~km}$ from each other, in two lines of 4.5 to 5 $\mathrm{km}$ (Tobler et al. 2008), covering an area of $10 \mathrm{~km}^{2}$ approximately. The lines were positioned perpendicularly to the Purus River (Figure 1), as well as by Borges et al. (2015) in Chandless State Park, near to Purus Project. No baits were used at the sampling stations. The traps operated continuously ( 24 hours a day) for 120 days in the first sampling campaign (June 2013 to September 2013) and 150 days during the second campaign (December 2013 to May 2014). The traps were programmed to shoot at intervals of 30 seconds between the photos, always making double shots to help identify the species. During the field work for the installation of traps, occasional mammalian recordings were carried out by visualization, vocalization and traces.

The conservation status of species was classified according to categories used by the International Union for the Conservation of Nature (IUCN) and the Red Book of Brazilian Fauna Threatened with Extinction (MMA 2014). We used the relative abundance index (RAI) as a measure of the abundance of species in each trap station, since relative abundance indices have strong relation with the abundance of a species (Carbone et al. 2002, O'Brien et al. 2003).

The RAI consists of the number of independent records of a given species at a station, divided by the number of days of operation of this collection station multiplied by 100 (ind/100 night-traps). Each record was considered independent if: (1) the interval between consecutive photos of the same species is greater than $1 \mathrm{~h}$; (2) photographs of

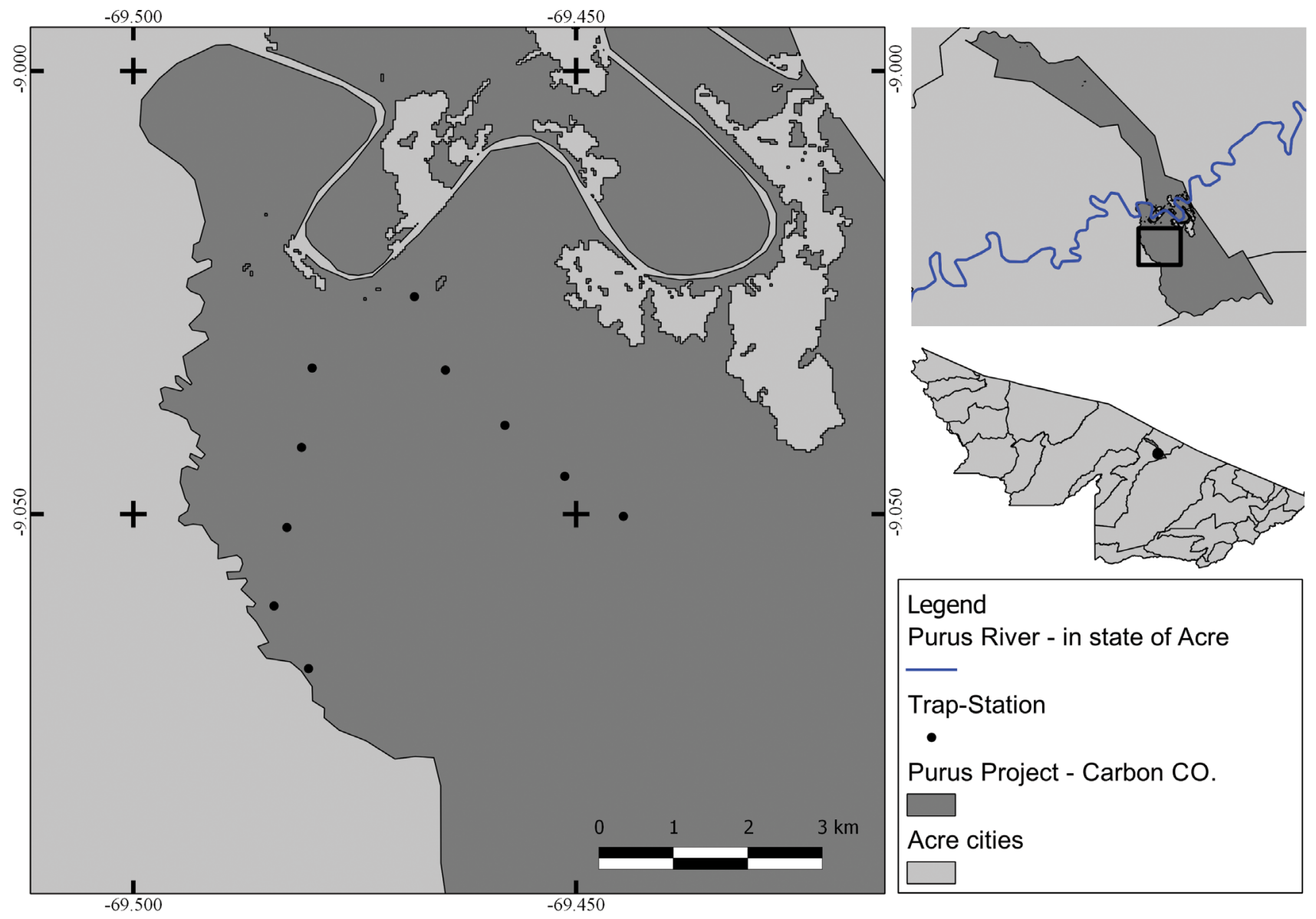

Figure 1. Location of the Purus Project and camera-traps stations in Manoel Urbano, Acre, Brazil. 
different individuals of the same species when differentiation was possible (O'Brien et al. 2003). Social species in which more than one individual is recorded in the same photo are considered a single record, so the relative abundance of Pecari tajacu, for example, is given as the no. of groups/100 night-traps. The activity pattern was estimated for species that had more than nine independent records (Harmsen et al. 2010). The number of records was counted at 1-hour intervals.

To evaluate if the sampling effort was enough to record most of the species in the area, accumulation curves were constructed by plotting the number of species observed as a function of the sampling effort of night-traps using 1000 randomizations (observed richness - Mao Tao). Species richness expected for the area was estimated using the richness estimator Jack-knife 1. As the method using camera-traps is not a suitable method for primate studies, records of such individuals were excluded from these analyses.

\section{Results}

With an effort of 1,859 night-traps, a total of 22 species of mammals (including three species of primates) were recorded, distributed in nine orders and 15 families. Occasional visualizations and traces were added and the number of mammal taxa recorded in the Purus Project reaches 27 (Table 1). The richest order, including occasional visualization and trace data, was Primates with seven species, followed by the order Carnivora with six.

With a total of 19 species, the cumulative curve of species showed no tendency to reach asymptote, which suggests the registration of new species with increased sampling effort. According to the richness estimator Jack-knife 1, the species richness estimated for the area is of 22 species (Figure 2).

The most abundant species were Pecari tajacu (1.56), followed by Dasyprocta sp. (1.51) and Mazama americana (1.18) (Table 1). Among the recorded species, two are considered endangered (Tapirus terrestris and Myrmecophaga tridactyla) (Figure 3) and four others are data deficient species (Table 1), based on the lists of endangered species of IUCN or MMA. Most species had a predominantly diurnal activity pattern, A. microtys and Dasyprocta $\mathrm{sp}$. showed activity pattern throughout the day, starting at sunrise reducing to sunset, while $M$. pratti has your activity peak at sunrise and sunset only, and E. barbara started from sunrise ending at 14:00. Only four species presented higher nocturnal activity, Dasypus sp. with activity peak between 20:00 and 23:00, C. paca and L. pardalis at midnight and the dawn, T. terrestris showed your activity peak at 22:00 reducing your activity at the dawn, at 04:00, with some records during the day (Figure 3).

\section{Discussion}

The Purus Project area presented a considerable richness of medium and large terrestrial mammals with 22 species are registred, results close to those found in conservation units such as Alto Tarauacá Extractive Reserve with 23 (Botelho 2013), 25 in Los Amigos, Peru (Tobler et al. 2008) and 27 in Chandless State Park, Acre (Borges et al. 2015). Although there is a difference in the sample effort employed, this finding is of high importance, since private areas may be of great value for the conservation of mammals and ecosystems as a whole (Gallo et al. 2009, Negrões et al. 2011), especially if allied with REDD+ goals and plans.
The number of species recorded in the Purus Project may be related to the fact that the area is poorly deforested and has a low human density, which is characterized by habitat quality and low hunting pressure. Several studies have demonstrated the deleterious effects of habitat fragmentation and high hunting pressure. These two factors are essential for maintaining biodiversity in Amazonian ecosystems, making it possible to achieve one of the REDD+, as demonstrated in Peres (2001) and Michalski \& Peres (2007). Robinson and Bennett (2000) argue that forest ecosystems have a capacity to support hunting pressure of up to one inhabitant per $\mathrm{km}^{2}$. As in the Purus Project the human density is approximately $0.29 \mathrm{hab} / \mathrm{km}^{2}$ (approximately 100 $\mathrm{hab} / 347.02 \mathrm{~km}^{2}$ ) there is a greater probability of registering species susceptible to hunting pressure such as the tapir.

Among the species of mammals registered in the Purus Project area, two are categorized on the lists of endangered species of IUCN and MMA. Despite the large living area, such species are susceptible to hunting pressure and habitat loss. The tapir (Tapirus terrestris), for example, is a targeted species by hunters and is vulnerable, with slow reproduction, and can quickly suffer a reduction of its abundance in areas with high hunting pressure (Bodmer et al. 1997, Peres 2000a, Calouro 2005). Considered the largest terrestrial mammal in South America, the tapir is categorized as vulnerable to extinction by the International Union for the Conservation of Nature (IUCN). A possible extinction of this species entails the loss of a large number of ecosystem services, as a function of which it participates in processes such as dispersal, predation and grazing (of small seedlings). Therefore, acting in the control of plant populations and considered a key species for seed dispersal in the forest, especially large ones (Peres et al. 2016).

The record of naturally rare species, like Cabassous unicinctus and Atleocynus microtis (Leite-Pitman \& Williams 2011, Anacleto et al. 2013), in the Purus Project area, demonstrating the additional role of REDD+ in fill gaps in the distribution of these species and to contribute with information about their ecology. C. unicinctus, for example, is a rare armadillo, with only a few records confirmed in the Amazon (Tobler et al. 2008, Anacleto et al. 2013). The also rare short-eared $\operatorname{dog}$ (A. microtis), also known as the short-eared fox, draws attention to the high number of records in the Purus Project. This species of fox was recorded 12 times in six different collecting seasons. The relative abundance of $0.65 \mathrm{ind} / 100$ night-trap is among the highest recorded so far elsewhere in the Amazon, (Tobler et al. 2008) with about 2.9 ind/1000 night-traps in the Peruvian Amazon, (Koester et al. 2008) in the Jamari National Forest in Rondônia (Pimenta 2012) and even in the lower Purus have a relative abundance of 0.45 . Information on Atelocynus microtis is extremely scarce. It is known that the species is the most solitary of the South American canids, has an omnivorous diet and its main habitat is near water bodies (Leite-Pitman \& Williams 2011). In the Purus Project, all canine records were made of solitary individuals, it is noteworthy that none of the capture stations were mounted along water bodies.

Although not considered endangered, or even considered rare, the record of the puma (Puma concolor) is important in the study area. Because it is a large feline, the puma is a key species for the functioning of ecosystems (Terborgh et al. 2001). Through ingestion of their prey, large predators perform top-down control in ecosystems contributing to their balance and diversity (Estes et al. 2011). Another feline that plays a similar role in the control of species is the ocelot 
Mammals in a REDD+ project área

Table 1. Mammals recorded through camera-trap in the Purus Project. Record type: P (camera-trap), T (trace), V (visualization), Voc (vocalization). RAI: No. of records in camera-traps/effort x 100. Conservation status: LC (Least Concern), VU (Vulnerable), DD (Data Deficient) and NT (Near Threatened), according to the Ministry of Environment (MMA) (2014) and International Union for the Conservation of Nature (IUCN) (2017).

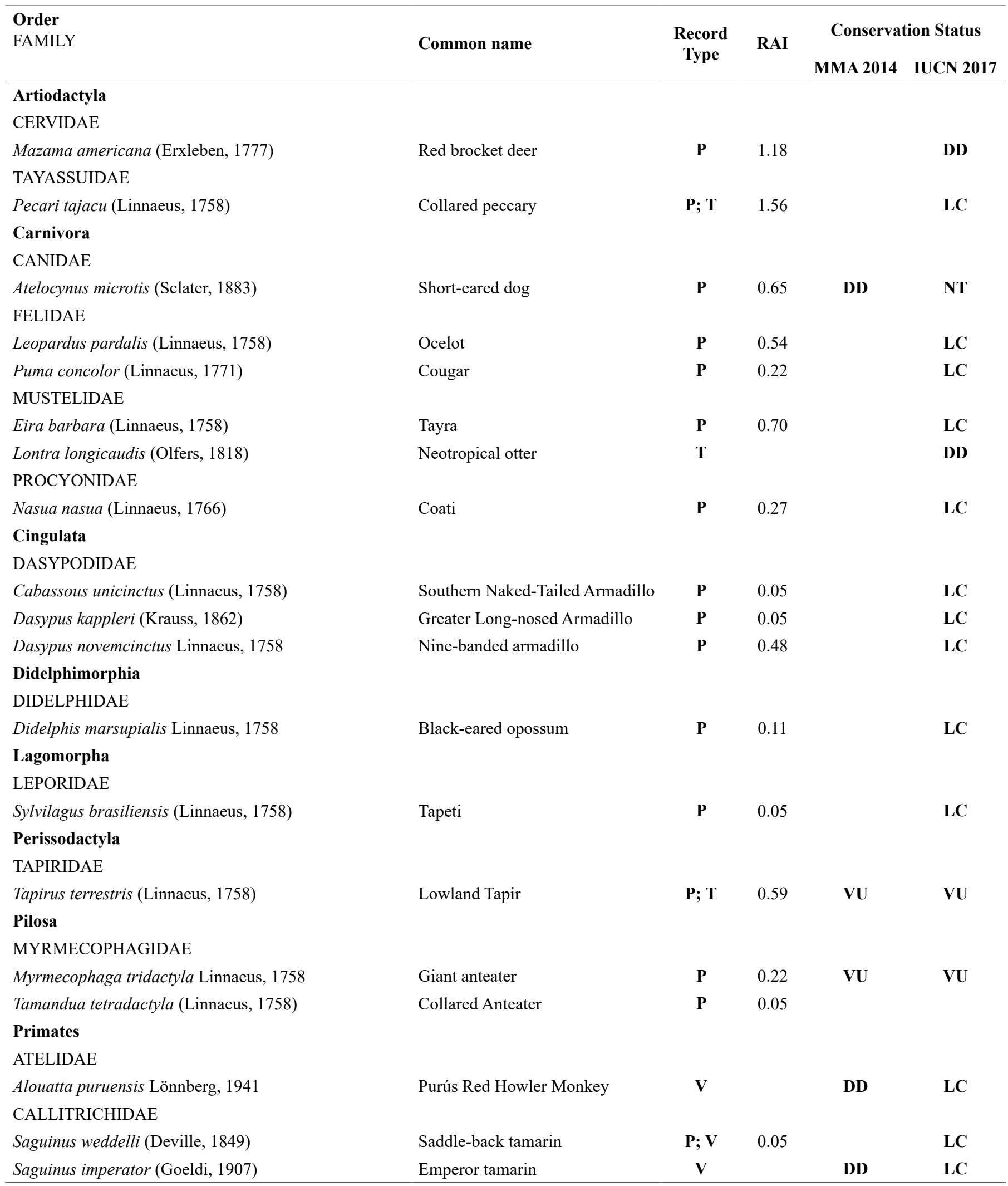


Continued Table 1.

\begin{tabular}{|c|c|c|c|c|c|}
\hline \multirow[t]{2}{*}{$\begin{array}{l}\text { Order } \\
\text { FAMILY }\end{array}$} & \multirow{2}{*}{ Common name } & \multirow{2}{*}{$\begin{array}{c}\text { Record } \\
\text { Type }\end{array}$} & \multirow{2}{*}{ RAI } & \multicolumn{2}{|c|}{ Conservation Status } \\
\hline & & & & MМА 2014 & IUCN 2017 \\
\hline \multicolumn{6}{|l|}{ CEBIDAE } \\
\hline Cebus unicolor Spix, 1823 & Spix's White-fronted Capuchin & $\mathbf{P}$ & 0.05 & & $\mathbf{L C}$ \\
\hline Saimiri boliviensis (I. Geoffroy \& de Blainville,1834) & Bolivian squirrel monkey & $\mathbf{P} ; \mathbf{V}$ & 0.05 & & $\mathbf{L C}$ \\
\hline Pithecia mittermeieri Gray, 1842 & Gray's Bald-faced Saki & $\mathbf{V}$ & & & $\mathbf{L C}$ \\
\hline \multicolumn{6}{|l|}{ Rodentia } \\
\hline \multicolumn{6}{|l|}{ CUNICULIDAE } \\
\hline Cuniculus paca (Linnaeus, 1766) & Spotted paca & $\mathbf{P}$ & 0.43 & & $\mathbf{L C}$ \\
\hline \multicolumn{6}{|l|}{ SCIURIDAE } \\
\hline Hadrosciurus spadiceus Olfers, 1818 & Southern Amazon red squirrel & $\mathbf{P}$ & 0.38 & & $\mathbf{L C}$ \\
\hline
\end{tabular}

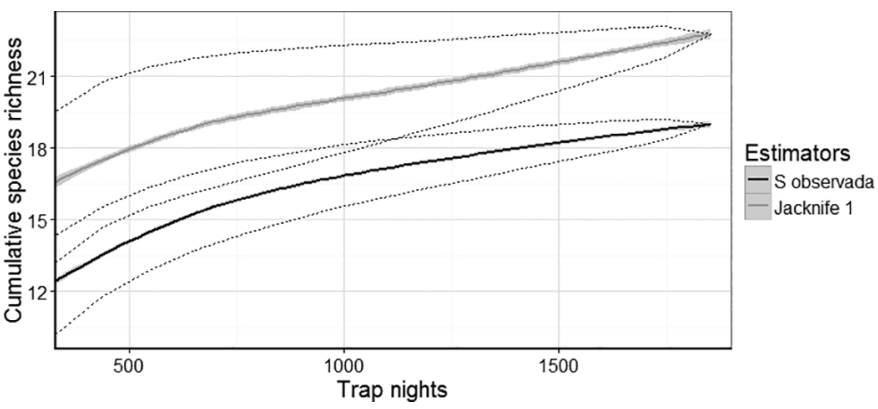

Figure 2. Cumulative curve of species (with standard deviation) of medium and large mammals registered at the Purus Project, Manoel Urbano - Acre.

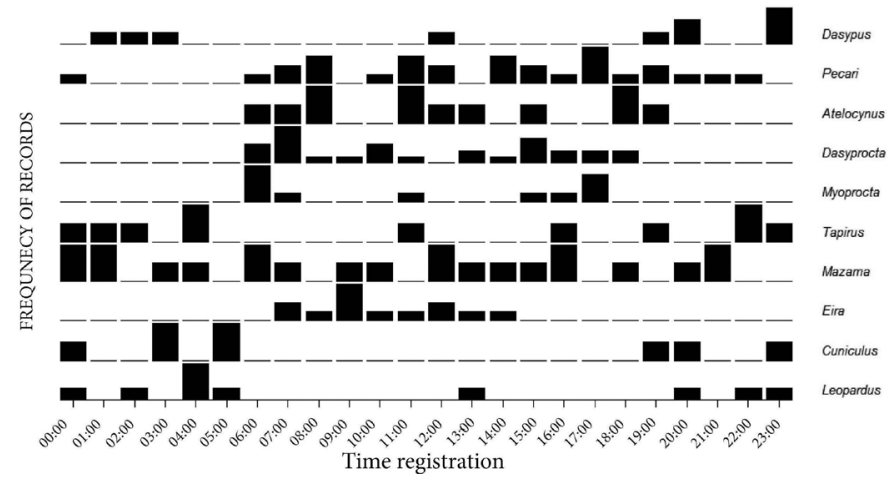

Figure 3. Summary of the activity pattern of the major taxa recorded in the Purus Project, Manoel Urbano, Acre.

(Leopardus pardalis), however, its relationship is with smaller prey, such as rats and marsupials of less than $1 \mathrm{~kg}$, and even agouties. Through the predation of more competitive prey, ocelot contributes to a greater diversity of small mammals (Fonseca \& Robinson 1990). Even with their great importance for the functioning of the ecosystem, felines are the target of conflicts with humans, especially in areas of high population density, because of the predation of domestic animals
(Michalski et al. 2006, Marchini \& Macdonald 2012). The relative abundance of these species in this region is considerable, especially due to the existence of residents.

The activity patterns of the species follow the description by Negrões (2011), and observerd by Botelho (2013) in RESEX Alto Tarauacá, Acre, Brazil. The high number of diurnal records of red deer, for example, is important. It is known that the species has a pattern of caternal activity (diurnal, crepuscular and nocturnal) (Azevedo 2008), but in areas with high hunting pressure, the species shows a decrease in the amount of diurnal records (Di Bitetti et al. 2008). Similarly, $P$. tajacu and $T$. terrestris presents activity pattern at day and night with different peaks. We observed that the three rodent's species presented differentiation in the activity pattern in response to a possible niche overlap, however more studies are needed to understand the patterns involved.

The richness of mammal species recorded through camera-traps in this study area underscores the importance of REDD + projects in private areas for conservation, in view of the increasing challenges of inclusion and creation of new public protected areas and showed that most of the goals set by the project are met at this moment. Of the 21 conservation units in the state of Acre, only five have studies focusing on the mammal community. The Purus Project area surpasses the size of two protected areas (Area of Relevant Ecological Interest Japiim-Pentecoste and São Francisco National Forest) in the state and is near two other units, which highlights the importance of this area for conservation of biodiversity and demonstrates the potential of private areas for mammal conservation.

In the State of Acre, more specifically in the Purus River, information and even inventories of medium and large mammals are scarce. Thus, this initial study of mammals in the Purus Project area may serve as a basis for studies aimed at understanding the conservation status of mammals in the region, and in REDD+ project areas. REDD+ projects have, at times, difficulty on establishing plans and goals for the conservation of biodiversity (Panfil \& Harvey 2016). Therefore, studies 
such as the one presented here, should increase in order to improve discussions and align methods of biodiversity monitoring in REDD+ projects, especially with cameras-traps since it allows comparisons at a global level (O'Brien et al. 2010, Rich et al. 2017).

Although, on average, have large home ranges and a wide distribution, medium and large mammals have been suffering increasingly with the rapid habitat reduction in recent years. The existence of private protected areas and the establishment of REDD+ project goals, can become an important component for the conservation of species and for the connection between UCs favoring the dispersion of species and populations between areas, and will consequently promote gene flow.

\section{Acknowledgements}

We are grateful to CarbonCo (the subsidiary of Carbonfund.org Foundation) for the financial cost of the field work, and to Kidney da Cunha Aires for assisting in the field activities with the camera-traps.

\section{Author Contributions}

André Luis Moura Botelho: Substantial contribution to the design and design of the work; data acquisition, analysis and writing of the paper.

Luiz Henrique Medeiros Borges: Contribution in the analysis and interpretation of data, in the writing of the work and critical review adding intellectual content.

Brian McFarland: Contribution in the writing of the work and critical review adding intellectual content.

\section{Conflicts of interest}

The authors declare that they have no conflict of interest related to the publication of this manuscript.

\section{References}

ANACLETO, T.C.S., GODOY, L. P. \& TUBELIS, D. P. 2013. New records of the southern naked-tailed armadillo Cabassous unicinctus unicinctus Linnaeus, 1758 (Cingulata: Dasypodidae) in Brazil. Biota Neotropica 13(2):293-296. http://www.biotaneotropica.org.br/v13n2/en/abstract?shortcommunication+bn00213022013.

AZEVEDO, A.D.K. 2008. Análise comparativa do período de atividade entre duas populações de Mazama americana (veado-mateiro). Dissertação de mestrado, Universidade de São Paulo, São Paulo, Brazil.

BELLO, C., GALETTI, M., PIZO, M.A., MAGNAGO, L.F.S., ROCHA, M.F., LIMA, R.A.F., PERES, C.A., OVASKAINEN, O. \& JORDANO, P. 2015. Defaunation affects carbon storage in tropical forests. Science Advances 1(11): e1501105.

BENCHIMOL, M. \& PERES, C.A. 2015. Predicting local extinctions of Amazonia vertebrates in forest islands created by a mega dam. Biological Conservation 187:61-72.

BODMER, R.E., EISENBERG, J.F. \& REDFORD, K.H. 1997. Hunting and the likelihood of extinction of Amazonian mammals. Conservation Biology 11:460-466.

BORGES, L.H.M., CALOURO, A.M. \& SOUSA, J.R. 2015. Large and medium-sized mammals from Chandless State Park, Acre, Brazil. Mastozoologia Neotropical 22(2):265-277.
BORGES, L.H.M., CALOURO, A.M., BOTELHO, A.L.M. \& SILVEIRA, M. 2014. Diversity and habitat preference of medium and large-sized mammals in an urban forest fragment of southwestern Amazon. Iheringia 104(2):168-174.

BOTELHO, A.L. 2013. Caça de subsistência e os mamíferos da RESEX do Alto Tarauacá, Acre. Dissertação de mestrado, Universidade Federal do Acre, Acre, Brazil.

BOTELHO, A.L.M., CALOURO, A.M., BORGES, L.H.M. \& CHAVES, W.A. 2012. Large and medium-sized mammals of the Humaitá Forest Reserve, southwestern Amazonia, state of Acre, Brazil. Check List $8(6): 1190-1195$.

BROWN, J.H. 2014. Why are there so many species in the tropics? Journal of Biogeography 41:8-22.

CALOURO, A.M. 2005. Análise do manejo florestal de baixo impacto e a caça de subsistência na comunidade de primatas da Floresta Estadual do Antimary (Acre, Brazil). Tese de doutorado, Universidade Federal de São Carlos (UFSCar), São Paulo, Brazil.

CARbone, C., Christie, S., CONFOrti, A., COUlson, T., FRANKLIN, N., GINSBERG, J.R., GRIFFITHS, M., HOLDEN, J., KAWANISHI, K., KINNAIRD, M., LAINDLAW, R., LYNAM, A., MACDONALD, D.W., MARTYR, D., MCDOUGAL, C., NATH, L., O'BRIEN, T.G., SEIDENSTICKER, J., SMITH, D.J.L., SUNQUIST, M.E., TILSON, R., WAN \& SHAHRUNDDIN, W. 2002. The use of photographic rates to estimate densities of tigers and other cryptic mammals: a comment on misleading conclusions. Animal Conservation 5:119-120.

CULOT, L., BELLO, C., BATISTA, J.L.F., COUTO, H.T.Z. \& GALETTI, M. 2017. Synergistic effects of seed disperser and predator loss on recruitment success and long-term consequences for carbon stocks in tropical rainforests. Scientific Reports 7:7662.

DI BITETTI, M.S., PAVIOLO, A., FERRARI, C.A., DE ANGELO, C. \& DI BLANCO, Y. 2008. Differential Responses to Hunting in Two Sympatric Species of Brocket Deer (Mazama americana and M. nana). Biotropica 40:636-645.

DIRZO, R., YOUNG, H.S., GALETTI, M., CEBALlOS, G., ISAAC, N.J.B. \& COLLEN, B. 2014. Defaunation in the Anthropocene. Science 345:401-406

EATON, J. \& ANDRADE, I.A. 2012. Forest biomass carbon inventory for the Purus REDD Project, Acre State, Brazil. TerraCarbon Technical Report: $1-32$.

ESTES, J.A., TERBORGH, J., BRASHARES, J.S., POWER, M.E., BERGER, J., BOND, W.J., CARPENTER, S.R., ESSINGTON, T.E., HOLT, R. D., JACKSON, J. B.C., MARQUIS, R.J., OKSANEN, L., OKSANEN, T., PAINE, R.T., PIKITCH, E.K., RIPPLE, W.J., SANDIN, S.A., SCHEFFER, M., SCHOENER, T.W., SHURIN, J.B., SINCLAIR, A.R.E., SOULÉ, M.E., VIRTANEN, R. \& WARDLE, D.A. 2011. Trophic Downgrading of Planet Earth. Science 333:301-306.

FONSECA, G.A.B. \& ROBINSON, J.G. 1990. Forest size and structure: Competitive and predatory effects on small mammal communities. Biological Conservation 53:265-294.

GALLO, J.A., PASQUINI, L., REYERS, B. \& COWLING, R.M. 2009. The role of private conservation areas in biodiversity representation and target achievement within the Little Karoo region, South Africa. Biological Conservation 142:446-454.

HARMSEN, B.J., FOSTER, R.J., SILVER, S.C., OSTRO, L.E.T. \& DONCASTER, C.P. 2010. Jaguar and puma activity patterns in relation to their main prey. Mammalian Biology 76:320-324.

HARVEY, C.A, DICKSON, B. \& KORMOS C. 2010. Opportunities for achieving biodiversity conservation through REDD. Conservation Letters 3:53-61.

INPE - Instituto Nacional de Pesquisas Espaciais. 2016. Estimativas Anuais das Taxas de Desmatamento na Amazônia Geradas pelo Relatório do Projeto PRODES. Available at $<\mathrm{http}: / /$ www.obt.inpe. br/prodes/prodes 19882011. $\mathrm{htm}>$. Last acess in 25 November 2016. 
KOESTER, A., AZEVEDO, C.R., VOGLIOTTI, A. \& DUARTE, M.J.B. 2008. Occurrence of Atelocynus microtis (Sclater, 1882) in the Jamari National Forest, State of Rondônia. Biota Neotropica 8:645-659. http:// dx.doi.org/10.1590/S1676-06032008000400024

LEITE-PITMAN, M.R.P. \& WILLIANMS, R.S.R. 2011. Atelocynus microtis. The IUCN Red List of Threatened Species 2011: e T6924A12814890. http:// dx.doi.org/10.2305/IUCN.UK.2011-2 .RLTS.T6924A12814890.en. Last acess in 26 April 2017.

MARCHINI, S., \& MACDONALD, D.W. 2012. Predicting ranchers' intention to kill jaguars: Case studies in Amazonia and Pantanal. Biological Conservation 147:213-221.

MARQUES, A.A.B, \& PERES, C.A. 2015. Pervasive legal threats to protected areas in Brazil. Oryx 49:25-29.

MARTINS, S.S., SANDERSON, J.G. \& SILVA-JUNIOR, J.S. 2007. Monitoring mammals in the Caxiuana National Forest, Brazil - First results from the Tropical Ecology, Assessment and Monitoring (TEAM) program. Biodiversity \& Conservation 16:857-870

MAURY, C.M. 2002. Avaliação e identificação de áreas e ações prioritárias para conservação, utilização sustentável e repartição dos benefícios da biodiversidade nos biomas brasileiros. Ministério do Meio Ambiente, Brasília.

MICHALSKI F., BOUHLOSA, R.L.P., FARIA, A. \& PERES, C.A. 2006. Human-wildlife conflicts in a fragmented Amazonian forest landscape: determinants of large felid depredation on livestock. Animal Conservation 9:179-188.

MICHALSKI, F. \& PERES, C.A. 2007. Disturbance-Mediated Mammal Persistence and Abundance-Area Relationships in Amazonian Forest Fragments. Conservation Biology 21:1626-1640.

MINISTÉRIO DO MEIO AMBIENTE. 2002. Avaliação e Identificação de áreas prioritárias para conservação, utilização sustentável e repartição dos benefícios da biodiversidade nos biomas brasileiros. Brasília, DF.

MINISTERIO DO MEIO AMBIENTE. 2014. Lista Nacional Oficial de Espécies da Fauna Ameaçada de Extinção. Portaria no 444, de 17 de dezembro de 2014. Ministério do Meio Ambiente. Diário Of. da União 121-126. Available at $<$ http://pesquisa.in.gov.br/imprensa/jsp/visualiza/index.jsp?jornal=1\&p agina $=121 \&$ data $=18 / 12 / 2014>$ last access in March 2018.

MMA - MINISTÉRIO DO MEIO AMBIENTE. 2017. Tabela consolidada de Unidades de Conservação. Fonte: CNUC/MMA - www.mma.gov.br/ cadastro_uc.

NEGRÕES, N., REVILlA, E., FONSECA, C., SOARES, A.M.V.M., JÁCOMO, A.T.A. \& SILVEIRA, L. 2011. Private forest reserves can aid in preserving the community of medium and large-sized vertebrates in the Amazon arc of deforestation. Biodiversity and Conservation 20:505-518.

NORTON, D.A. 2000. Conservation Biology and Private Land: Shifting the Focus. Conservation Biology 14:1221-1223.

O'BRIEN, T.G., BAILLIE, J.E.M., KRUEGER, L. \& CUKE, M. 2010. The wildlife picture index: monitoring top trophic levels. Animal Conservation. 13(4):335-343.

O'BRIEN, T.G., KINNAIRD, M.F. \& WIBISONO, H.T. 2003. Crouching Tiger, hidden prey: Sumatran tiger and prey populations in the tropical forest landscape. Animal Conservation 6:131-139.

OLIVEIRA, T.G., MAZIM, F.D., VIEIRA, O.Q., BARNETT, A.P.A., SILVA, G.N., SOARES, J.B.G., SANTOS,V.J.P., SILVA,V.F., ARAÚJO, P.A., TCHAIKA, L. \& MIRANDA, C.L. 2016. Nonvolant Mammal Megadiversity and Conservation Issues in a Threatened Central Amazonian Hotspot in Brazil. Tropical Conservation Science 9:1-16.
PAGLIA, A.P., FONSECA, G.A.B., RYLANDS, A.B., HERRMANN, G., AGUIAR, L.M.S., CHIARELLO, A.G., LEITE, Y.L.R., COSTA, L.P., SICILIANO, S., KIERULFF, M.C.M., MENDES, S.L., MITTERMEIER, R.A. \& PATTON, J.L. 2012. Annotated checklist of Brazilian mammals 2 ed. Occasional Papers in Conservation Biology, Brazil.

PANFIL, S.N. \& HARVEY, C.A. 2016. REDD+ and biodiversity conservation: a review of the biodiversity goals, monitoring methods, and impacts of 80 REDD+ projects. Conservation Letters 9(2):143-150.

PENCE, G.Q.K., BOTHA, M.A., \& TURPIE, J.K. 2003. Evaluating combinations of on-and off-reserve conservation strategies for the Agulhas Plain, South Africa: A financial perspective. Biological Conservation 112:253-273.

PERES, C.A, EMILIO, T., SCHIETTI, J., DESMOULIÈRE, S.J.M., \& LEVI, T. 2016. Dispersal limitation induces long-term biomass collapse in overhunted Amazonian forests. Proceedings of the National Academy of Sciences 113:892-897.

PERES, C.A. 2000a. Effects of subsistence hunting on vertebrate community structure in Amazonian forests. Conservation Biology 14:240-253.

PERES, C.A. 2000b. Identifying keystone plant resources in tropical forests: the case of gums from Parkia pods. Journal of Tropical Ecology 16:287-317.

PERES, C.A. 2001. Synergistic effects of subsistence hunting and habitat fragmentation on Amazonian forest vertebrates. Conservation Biology 15:1490-1505

PIMENTA, C.S. 2012. Habitat use and occupation for carnivores in a reservation of sustainable use in Central Amazonia, Brazil. Dissertação de mestrado, Instituto Nacional de Pesquisa da Amazônia, Amazonas, Brazil.

POLAK, T., WATSON, J.E.M., BENNETT, J.R., POSSINGHAM, H.P., FULLER, R.A. \& CARWARDINE, J. 2016. Balancing ecosystem and threatened species representation in protected areas and implications for nations achieving global conservation goals. Conservation Letters 9:438-455.

RICH, L.N., DAVIS, C.L., FARRIS, Z.J., MILLER, D.A.W., TUCKER, J.M., HAMEL, S., FARHADINIA, M.S., STEENWEG, R., DI BITETTI, M.S., THAPA, K., KANE, M.D., SUNARTO, S., ROBINSON, N.P., PAVIOLO, A., CRUZ, P., MARTINS, Q., GHOLIKHANI, N., TAKTEHRANI, A., WHITTINGTON, J., WIDODO, F.A., YOCCOZ, N.G., WULTSCH, C., HARMSEN, B.J. \& KELLY, M.J. 2017. Assessing global patterns in mammalian carnivore occupancy and richness by integrating local camera trap surveys. Global Ecology and Biogeography. 26(8):918-929.

ROBINSON, J.G. \& BENNETT, E.L. 2000. Carrying capacity limits to sustainability of subsistence hunting in tropical forest. In: Hunting for sustainability in Tropical Forest (J.G. Robinson \& E.L. Bennett, eds.)., Columbia University Press, New York, p. 13-30.

RODRIGUES, A.S.L., ANDELMAN, S.J., BAKARR, M.I., BOITANI, L., BROOKS, T.M., COWLING, R.M., FISHPOOL, L.D.C., FONSECA, G.A.B., GASTON, K.J., HOFFMANN, M., LONG, J. S., MARQUET, P. A., PILGRIM, J. D., PRESSEY, R. L., SCHIPPER, J., SECHREST, W., STUART, S. N., UNDERHILL, L. G., WALLER, R. W., WATTS, M. E. J. \& YAN X. 2004. Effectiveness of the global protected area network in representing species diversity. Nature 428(8):9-12.

ROUGET, M., RICHARDSON, D.M. \& COWLING, R.M. 2003. The current configuration of protected areas in the Cape Floristic Region, South Africa Reservation bias and representation of biodiversity patterns and processes. Biological Conservation 112:129-145. 
SCHIPPER, J., CHANSON, J.S., CHIOZZA, F., COX, N.A., HOFFMANN, M., KATARIYA, V., LAMOREUX, J., RODRIGUES, A.S.L., STUART, S.N., TEMPLE, H.J., BAILLIE, J., BOITANI, L., JR, T.E.L., MITTERMEIER, R.A., SMITH, A.T., ABSOLON, D., AGUIAR, J.M., AMORI, G., BAKKOUR, N., BALDI, R., BERRIDGE, R.J., BIELBY, J., BLACK, P.A., BLANC, J.J., BROOKS, T.M., BURTON, J.A., BUTYNSKI, T.M., CATULLO, G., GARSHELIS, D.L., GATES, C., GIMENEZ-DIXON, M., GONZALEZ, S., GONZALEZ-MAYA, J.F., GOOD, T.C., HAMMERSON, G., HAMMOND, P.S., HAPPOLD, D., HAPPOLD, M., HARE, J., HARRIS, R.B., HAWKINS, C.E., HAYWOOD, M., HEANEY, L.R., HEDGES, S., HELGEN, K.M., HILTON-TAYLOR, C., HUSSAIN, S.A., ISHII, N., JEFFERSON, T.A., JENKINS, R.K.B., JOHNSTON, C.H., KEITH, M., KINGDON, J., KNOX, D.H., KOVACS, K.M., LANGHAMMER, P., LEUS, K., LEWISON, R., LICHTENSTEIN, G., LOWRY, L.F., MACAVOY, Z., MEDELLÍN, R.A., MEDICI, P., MILLS, G., MOEHLMAN, P.D., MOLUR, S., MORA, A., NOWELL, K., OATES, J.F., OLECH, W., OLIVER, W.R.L., OPREA, M., PATTERSON, B.D., PERRIN, W.F., POLIDORO, B.A., POLLOCK, C., POWEL, A., PROTAS, Y., RACEY, P., RAGLE, J., RAMANI, P., RATHBUN, G., REEVES, R.R., REILLY, S.B., REYNOLDS, J.E., RONDININI, C., ROSELL-AMBAL, R.G., RULLI, M., RYLANDS, A.B., SAVINI, S., SCHANK, C.J., SECHREST, W., SELF-SUlliVAN, C., SHOEMAKER, A., SILlERO-ZUBIRI, C., SILVA, N., SMITH, D.E., TAYLOR, B.L., TIMMINS, R., TIRIRA, D.G., TOGNELLI, M.F., TSYTSULINA, K., VEIGA, L.M., VIÉ, J., WILLIAMSON, E.A., WYATT, S.A., XIE, Y. \& YOUNG, B.E.. 2008. The Status of the World's Land and Marine Mammals: Diversity, Threat, and Knowledge. Science 322:225-230.
SCOTT, J.M., DAVIS, F.W., MCGHIE, R.G., WRIGHT, R.G. \& ESTES, J. 2001. Nature Reserves: Do They Capture the Full Range of America's Biological Diversity? Ecological Applications 11:999-1007.

SEMA - SECRETARIA DE ESTADO DE MEIO AMBIENTE. 2010. Recursos naturais: biodiversidade e ambientes do acre. ZEE/AC, FASE II, ESCALA 1:250.000/PROGRAMA ESTADUAL DE ZONEAMENTO ECOLÓGICO. RIO BRANCO, ACRE.

SOARES-FILHO, B.S., NEPSTAD, D.C., CURRAN, L.M., CERQUEIRA, G.C., GARCIA, R.A., RAMOS, C.A., VOLL, E., MCDONALD, A., LEFEBVRE, P. \& SCHLESINGER, P. 2006. Modelling conservation in the Amazon basin. Nature 440:520-523.

STONER, K.E., VULINEC, K., WRIGHT, S.J. \& PERES, C.A. 2007. Hunting and Plant Community Dynamics in Tropical Forests: A Synthesis and Future Directions. Biotropica 39:385-392.

TERBORGH, J., NUÑEZ, G.I., PITMAN, N.C.A., CORNEJO, F.H.V, ALVAREZ, P., SWAMY, V., PRINGLE, E.G. \& PAINE, C.E.T. 2008. Tree recruitment in an empty forest. Ecology 89(6):1757-1768.

TERBORGH, J.W., LOPEZ, L., NUÑEZ, P.V, RAO, M., SHAHABUDDIN, G., ORIHUELA, G., RIVEROS, M., ASCANIO, R., ADLER, G.H., LAMBERT, T.D. \& BALBAS, L. 2001. Ecological Meltdown in Predator-Free Forest Fragments. Science 294:1923-1925.

TOBler, M.W., CARRILO-PERCASTEGUi, S.E., PITMAN, R.L., MARES, R. \& POWELL, G. 2008. An evaluation of camera traps for inventorying large and medium sized terrestrial rainforest mammals. Animal Conservation 11:169-178.

WATSON, J.E.M., DUDLEY, N., SEGAN, D.B. \& HOCKINGS, M. 2014. The performance and potential of protected areas. Nature 515:67-73.

Received: $19 / 11 / 2017$

Revised: 01/05/2018

Accepted: 04/06/2018

Published online: 02/07/2018 